\begin{tabular}{|l|l|l|}
\hline \multicolumn{2}{|c|}{ PublisherInfo } \\
\hline \hline PublisherName & $:$ & BioMed Central \\
\hline \hline PublisherLocation & $:$ & London \\
\hline \hline PublisherImprintName & $:$ & BioMed Central \\
\hline \hline
\end{tabular}

\title{
Regulating large chromatin domains
}

\begin{tabular}{|l|l|l||}
\hline \multicolumn{2}{|c|}{ ArticleInfo } \\
\hline \hline ArticleID & $:$ & 4610 \\
\hline \hline ArticleDOI & $:$ & $10.1186 /$ gb-spotlight-20021015-01 \\
\hline \hline ArticleCitationID & $:$ & spotlight-20021015-01 \\
\hline \hline ArticleSequenceNumber & $:$ & 276 \\
\hline \hline ArticleCategory & $:$ & Research news \\
\hline \hline ArticleFirstPage & $:$ & 1 \\
\hline \hline ArticleLastPage & $:$ & 2 \\
\hline \hline & $:$ & RegistrationDate : 2002-10-15 \\
ArticleHistory & $:$ & OnlineDate \\
\hline \hline ArticleCopyright & $:$ & BioMed Central Ltd2002-10-15 \\
\hline \hline ArticleGrants & $:$ & \\
\hline \hline ArticleContext & $:$ & 130593311 \\
\hline \hline
\end{tabular}




\section{Jonathan B Weitzman}

Email: jonathanweitzman@hotmail.com

The thymocyte-specific SATB1 (special AT-rich sequence binding 1) protein binds to base-unpairing regions (BURs) of chromosomal DNA within matrix-attachment regions (MARs) and assembles a SATB1 network structure that can regulate gene expression over relatively large distances. In the October 10 Nature, Yasui et al. describe biochemical analysis of SATB1 within BUR-binding complexes (Nature 2002, 419:641-645). They analysed extracts from the thymi of normal and knockout $\left(S A T B 1^{-/}\right)$mice and found that components of the NURD, CHRAC and ACF chromatin-remodelling complexes co-purified with SATB1. Immunoprecipitation analysis showed that SATB1 recruits histone deacetylases and remodelling complexes, and represses the IL-2Ralpha (inteleukin-2 receptor alpha gene) locus. Changes in nucleosome positioning in the absence of SATB1 could be observed as much as 8 kilobases away, suggesting that mechanisms of this sort play a general a role in global gene regulation.

\section{References}

1. A tissue-specific MAR/SAR DNA-binding protein with unusual binding site recognition.

2. Nature, [http://www.nature.com] 